\title{
Korean Bilingual Students' Strategic Employment of Translanguaging While Writing
}

\author{
Chaehyun Lee \\ Southeastern Oklahoma State University, Oklahoma, United States
}

\begin{abstract}
This qualitative study utilizes a heteroglossic perspective and discourse analysis methodology to examine why and for what purposes three Korean-American third-graders engaged in translanguaging practices while writing in a Korean heritage language (HL) classroom in the U.S. translanguaging refers to bilingual speakers' natural strategy when they utilize their full language linguistic repertoires from their two languages. In performing the analysis of translanguaging purposes, I categorize the students' written translanguaging purposes into four categories: sociolinguistic, metalinguistic, sociocultural, and metacognitive. The findings show that the emergent bilingual students utilize their linguistic resources from both their languages through translanguaging, and their translanguaging demonstrates their sociolinguistic competence, metalinguistic awareness, sociocultural understanding, and metacognitive insight. The fluid way that the students translanguaged while writing suggest that they were employing their integrated linguistic resources, rather than utilizing each language separately to write. The findings substantiate the use of heteroglossic perspective to explain bilingual students' utilization of two languages while writing.
\end{abstract}

Keywords: Korean-American bilingual, literacy, writing, translanguaging, heteroglossia

\section{Introduction}

Researchers interested in the language development and use of young emergent bilingual children in the U.S. have focused more on the children's development and use of their second language (L2, English) than on their first language (L1) or heritage language (HL) (August \& Shanahan, 2010; Goldenberg, 2011). For example, a number of researchers investigated how emergent bilinguals developed their English language and literacy skills (e.g., Francis, Lesaux, \& August, 2006; Genesee, Geva, Dressler, \& Kamil, 2006; Golberg, Paradis, \& Crago, 2008; Slavin \& Cheung, 2005). Yet, comparatively, little attention has been given to emergent bilinguals' language and literacy development in their HL (August \& Shanahan, 2010; Goldenberg, 2011; Lee \& García, 2020; Ro \& Cheatham, 2009).

Recently, scholars favored a heteroglossic perspective (Bakhtin, 1981) when it comes to investigating the literacy performance of bilingual students. According to the heteroglossic perspective, bilingual individuals are more likely to utilize what they know about reading and writing in both languages, drawing from their integrated language repertoire and linguistic resources (Canagarajah, 2013; García \& Wei, 2014; Wei, 2018). After García (2009) conceptualized the term "translanguaging", which refers to bi/multilinguals'

Chaehyun Lee, Ph.D., assistant professor, Department of Educational Instruction and Leadership, Southeastern Oklahoma State University, Oklahoma, United States. 
implementation of heteroglossic practices, such as the integrated use of their entire languages when communicating and making meanings, an increasing number of researchers employed the concept of translanguaging when examining bilingual students' language and literacy learning and development (García \& Leiva, 2014; McCarthey, Idelia, \& Lee, 2019).

Yet, most of the translanguaging studies have paid attention to Spanish-English bilingual students in dual-language (DL) bilingual programs by focusing on their spoken language use (e.g., Creese \& Blackledge, 2010; Durán \& Palmer, 2014; García-Mateus \& Palmer, 2017). Therefore, we have little understanding of how emergent bilingual children from other language minority groups in the U.S. (such as Korean-English bilinguals) engaged in translanguaging in other types of classroom settings (such as HL classrooms) when they employed translanguaging while writing (Lee \& García, 2020).

\section{Purpose of the Study}

To add to what is known about the role of the emergent bilingual students' HL in their bilingual development and performance, the present study investigates the Korean-English bilingual students' (third-graders) written language performance who attended American schools during the school week and a Korean HL School on Saturdays. The findings can help to fill the gaps in the field of bilingual/biliteracy research. First, in contrast to a DL setting, where students received instruction in both languages, which might prompt their thinking in both languages, this study was conducted in a Korean HL classroom, where the language of instruction is delivered in a target language only. Second, this study examined the translanguaging practices of bilingual students from two dissimilar languages-Korean and English, rather than from two ancestrally-related languages, such as Spanish and English. Third, the study focused on the students' written translanguaging when they engaged in writing task to document the written translanguaging practices of emergent bilingual students. The following research question guided my inquiry:

What characterized the Korean bilingual third-graders' written translanguaging in terms of its purposes and reasons?

\section{Theoretical Framework}

This study is situated within two major theoretical frameworks: (a) a sociocultural perspective on literacy (Street, 2001) and (b) theories on heteroglossia (Bakhtin, 1981) and translanguaging (García, 2009). Street (2001) proposed that to understand literacy practices, researchers should study them in-depth in different cultural contexts. He argued that literacy was shaped by social and cultural practices because it requires "thinking about ... doing and reading in cultural contexts". Street emphasized the social models of literacy in which participants negotiate and create meanings when they read and write in specific cultural contexts. Consistent with Street's view of literacy practices, we paid attention to the cultural contexts and social practices that surrounded the participating students' written language use and translanguaging practices. We employed the constructivist/interpretive paradigm (Mertens, 2015), which views reality as socially constructed because we wanted to understand how and why the participants socially constructed their translanguaging practices.

Bakhtin (1981) coined the term heteroglossia to explain speakers' simultaneous use of a diverse range of registers, voices, languages, or codes in their daily lives and authors' use of multiple voices in written texts. Recently, the Bakhtinian notion of heteroglossia has replaced monolingual ideology in research on 
bilingual students' language and literacy development. García (2009) conceptualized the term translanguaging to indicate the actual practices that bilingual individuals enact when employing heteroglossia. That is, translanguaging emphasizes bilingual students' fluid employment of their language and linguistic resources to communicate and make meaning both in orally and writing (Canagarajah, 2013; García \& Wei, 2014; Velasco \& García, 2014).

\section{Literature Reviews on Bilingual Students’ Translanguaging Practices When Writing}

Very few researchers investigated young bilingual students' employment of translanguaging while writing. Velasco and García (2014) reported that a few earlier researchers did not use the term translanguaging. However, researchers showed evidence of bilingual students' employment of translanguaging during the writing process, even when the writing was produced in only one language. For instance, Edelsky (1986) found that first-, second-, and third-grade Spanish-speaking students utilized their linguistic knowledge in Spanish when writing in English by using Spanish phonology (e.g., "ai joupllugouagientuscull [I hope you go again to school]" as cited in Velasco \& García, 2014, p. 8), but did not directly use Spanish words in their compositions. Soltero-Gonzalez and Butvilofsky (2016) reported similar findings for 28 Spanish-English bilingual preschoolers who attended a bilingual program. The students were asked to write familiar words (e.g., names of their family members/friends) and short sentences using high-frequency words in each language. Although they were given the writing tasks separately in each language, the preschoolers appeared to translanguage when they applied their knowledge of Spanish phonetics to write English words.

In one of the few studies that focused on the writing of Korean-English bilingual students, Nam (2017) investigated how 10 six-year-old Korean students who were learning English as a foreign language (EFL) in Korea understood the writing features that differentiate Korean and English. Nam reported that the young Korean students understood that Korean was a logographic language and had a shallow orthography and that English was an alphabetic language and had a deep orthography. Nam interpreted the findings as indicating that the young Korean students were becoming biliterate without any confusion.

Gort (2012) did not employ the word "translanguaging" in her qualitative study of bilingual Spanish-English first-graders' talk about writing. However, her analysis of what now is considered a translanguaging practice (code-switching) revealed that the bilingual students strategically utilized their oral language repertoires from both languages to talk about their writing. Gort also reported that one of the students displayed metacognitive awareness when she talked to herself in English about how she could revise her Spanish writing. Gort concluded that the student had engaged in bilingual metacognitive speech, which allowed her to reflect on her errors, rehearse the alternatives, and evaluate the effectiveness of the changes.

Other researchers reported that young bilingual students translanguaged to plan and compose their writing (Bauer, Presiado, \& Colomer, 2017; Velasco \& García, 2014). Bauer et al. (2017) employed qualitative methods to examine how two minority kindergarteners (a Spanish-speaking Latino student and an English-speaking African-American student) in a dual-language classroom worked as buddy pairs during writing activities. Bauer et al. (2017) reported that the two students supported and helped each other to develop their writing as they received each other's feedback. Through their bilingual dialogues, they scaffolded each other's language repertoires and writing while engaging in "metalinguistic talk" (p. 26).

Velasco and García (2014) explored the extent to which bilingual learners demonstrated translanguaging practices when they received writing instruction in one language. They used a case study methodology to 
investigate the written translanguaging practices of 24 bilingual Korean-English and Spanish-English students in Grade K-4 who were in dual-language classrooms. Only eight of the 24 writing samples demonstrated any translanguaging, leading them to question why so few of the students had employed translanguaging while writing. They wondered if the dual language context, in which there was strict adherence to monoglossic instruction, might have affected the students' translanguaging. Nonetheless, their analysis of five writing samples showed that the bilingual students translanguaged during different writing stages to plan, draft, and produce final compositions.

\section{Methods}

I employed qualitative discourse analysis (Gee, 2012) methodology to document, analyze, and interpret for what purposes and why the selected Korean-American students employed translanguaging when they wrote HL school assignments. Because I wanted to understand why the bilingual students engaged in translanguaging when writing, I also conducted semi-structured, open-ended interviews with the students about their written translanguaging.

\section{Research Context}

Data collection took place over 14 weeks during the spring semester in a first-grade classroom at a Korean HL school in a university town in the Midwest. The HL school was funded by Korean parents who wanted to support their children's HL learning and development. The school provided formal instruction in Korean for approximately 100 students enrolled in pre-K through Grade 5 each year, with five to 10 students in each class. Most of the enrolled students were second-generation Korean-Americans who were born in the U.S. after their parents had immigrated to the U.S.; a smaller number of students were first-generation Korean immigrant students, who were born in Korea and moved to the U.S. with their families. The Korean children attended the school during the school year on Saturdays from 10:20 a.m. to 1:20 p.m. Pseudonyms were used for all the participants.

\section{Participants}

Students. This paper focused on three of the five third-graders who attended the third-grade HL class at the Korean HL school. The three students were second-generation Korean-Americans and purposely selected as the participants for this study since they felt comfortable using English and often employed translanguaging when speaking in the classroom. The three students (two females-Julie and Suji, and one male-Toni) all were born in the U.S. and attended all-English schools during the school week and the Korean HL school on Saturdays. All three students had attended the Korean HL school since kindergarten. The students reported using English at the all-American schools during the school week and Korean with their parents at home. All the students and their families spent one month each year visiting relatives in Korea.

The third-grade teacher. The third-grade teacher (Mrs. Joen) participated in the study. Mrs. Joen was a female native Korean speaker. She came to the U.S. three years before the data collection of this study with her husband. She self-reported her English skill as intermediate in terms of listening comprehension but as basic regarding speaking proficiency. It was her second year as a third-grade teacher at the HL school.

The researcher. I am a native Korean speaker from South Korean and bilingual in Korean and English. I was the first-grade teacher in the same Korean HL school during the data collection of this study, and it was my fifth year of teaching as a first-grade teacher. 
Table 1

Description of Students

\begin{tabular}{|c|c|c|c|c|c|c|}
\hline Names & Age & Gender & Birthplace & $\begin{array}{l}\text { Preferred and } \\
\text { dominant language }\end{array}$ & Home language & $\begin{array}{l}\text { Time at Korean } \\
\text { language school }\end{array}$ \\
\hline Toni & 8.4 years old & Male & U.S. & English & Korean & 3.5 years \\
\hline Julie & 8.6 years old & Female & U.S. & English & Korean & Three years \\
\hline Suji & 8.2 years old & Female & U.S. & English & Korean & Three years \\
\hline
\end{tabular}

\section{Data Collection Sources and Procedures}

Instruction and language use in the third-grade HL classroom. The school day in the third-grade classroom was designed by the school and consisted of three parts. During the first part (50 minutes), the teacher (Mrs. Joen) used Korean to teach Korean language and literacy skills, culture, and history from a Korean government textbook. The second part was recess for 15-20 minutes, during which the students were free to use Korean and/or English. During the third and final part, the students participated in Korean book reading and discussion (50 minutes) and in-class writing (50 minutes) for a total of 100 minutes. During the writing sessions, Mrs. Joen held individual writing conferences for five to 10 minutes with each student weekly. The third-grade teacher spoke in Korean but sometimes employed English to ensure that the less Korean-proficient students comprehended what she had said in Korean. Mrs. Joen encouraged her third-graders to speak and write in Korean, but she accepted their use of English in her classroom.

Writing samples. I collected and analyzed all the writing that the third-graders completed in the HL class during the 14 weeks of the study. In addition, I collected two diary entries that the students wrote at home for homework each week. For the in-class writing assignments, the students wrote about the books that had been read during the reading sessions. Sometimes, the students were asked to retell the stories by thinking about the characters, plots, or specific events. Other times, they were asked to choose their favorite scene or part of the story, to address their reasons for their selection, and to expand their thoughts about the scene or part. For the diary entries, the students did free writing in Korean as homework based on what they have done on a particular date. For in-class writing, Mrs. Joen gave the class sheets of paper that had spaces both for writing and drawing. Thus, all the third-graders' in-class writing included drawings that describe their writing. While, the third-graders prepared their notebook for their diary entries, and two students (Toni and Julie) chose their notebooks that have lines only. Hence, not all of their diary entries included drawings. I collected a total of 97 writing samples from the three third-graders: 34 from Toni, 32 from Suji, and 31 from Julie.

Audio-recordings of student talk during the writing sessions. The students' talk with Mrs. Joen and each other during the writing sessions was audio-recorded over 14 weeks, and they were transcribed later. The audio-recordings captured approximately 650 minutes of the students' writing-related talk as well as their self-talk while engaging in drafting or during their pre-writing stages.

Student interviews. Each of the third-graders participated in two semi-structured, open-ended individual interviews for 15-20 minutes each with the researcher at the beginning and end of the study. The interviews were held after class at the Korean HL school and were audio-recorded and later transcribed. I initially asked each student questions in Korean. When the students did not understand what I had asked in Korean, I repeated the questions in English and told them to answer in their preferred language. During the first interview, the students answered five questions about their language preferences and proficiencies, four about their language use at home, and one about their ethnic/national identity. During the second interview, I asked questions based 
on a preliminary analysis of the individual student's translanguaging practices while writing. I provided the students with examples of their written translanguaging and asked them specific questions about their written language use.

\section{Data Analysis}

First, I analyzed the students' writing samples and the transcripts of their talk during the writing sessions. To calculate how often the students translanguaged when they wrote, I first counted the total number of writing samples that each student turned in for the HL writing assignments and diary entries. Next, I counted the number of writing samples that included written translanguaging in the texts and the spaces for the drawings. I identified written translanguaging as when the students employed two languages in written texts and drawing spaces.

After identifying each instance of translanguaging in the students' writing, I employed a coding framework, which I developed to categorize the written translanguaging purposes into four categories: sociolinguistic, metalinguistic, metacognitive, and sociocultural. I coded the students' use of translanguaging as demonstrating their sociolinguistic competence (Canale \& Swain, 1980) when they employed their linguistic resources (i.e., two languages) appropriately for social contexts in terms of the word choice, topic, setting, and relationship with others (Halliday \& Hasan, 1989). I coded their translanguaging as metalinguistic awareness when they demonstrated an understanding of their written language use and their ability to apply their linguistic knowledge about the two languages (Bialystok, 1991). I coded the students' translanguaging as their sociocultural understanding when they employed culturally familiar or culturally relevant words in their writing. Translanguaging that involved inner speech while writing was coded as metacognitive insight (Meichenbaum, 1985). I also analyzed the students' interviews about their use of Korean, English, and translanguaging when they wrote. The students' verbal reports from their interviews further explained the purposes and reasons for their written translanguaging.

It is important to note that the four categories were not mutually exclusive because one translanguaging instance sometimes served two purposes. For instance, when a student wrote a sentence by utilizing his/her dual lexicon knowledge, I analyzed its purpose as sociolinguistic competence. Yet, if the student demonstrated his/her understanding of using dual lexicon while writing, I also categorized the same translanguaging instance as demonstrating his/her metalinguistic awareness.

\section{Findings}

\section{The Nature of the Third-Grade Bilingual Students' Translanguaging While Writing}

Table 2 shows how often the third-graders translanguaged in their writing for each of the four major purposes identified in the written data (sociolinguistic, metalinguistic, metacognitive, and sociocultural). All three third-graders translanguaged the most for sociolinguistic purposes, accounting for $54-50 \%$ of their translanguaging. The second most frequent function for the students was metalinguistic awareness, which characterized $42-30 \%$ of their translanguaging practices. The third most frequent function was translanguaging for socio-cultural purposes, which occurred in the students' translanguaging between $9 \%$ and $4 \%$ of the time. Only Toni demonstrated translanguaging for metacognitive purposes (4\% of the time). Below I present a thematic portrayal of the three bilingual Korean-American third-graders' translanguaging practices in terms of the purposes for their translanguaging and how and why they translanguaged. 
Table 2

Number of Writing Samples and Purposes for Written Translanguaging by Student

\begin{tabular}{|c|c|c|c|}
\hline & Toni & Julie & Suji \\
\hline Number of writing samples & 34 & 31 & 32 \\
\hline Number of writing samples with written translanguaging & 22 & 27 & 29 \\
\hline Number of instances for sociolinguistic purposes & $\begin{array}{l}13 \\
(50 \%)\end{array}$ & $\begin{array}{l}21 \\
(51 \%)\end{array}$ & $\begin{array}{l}29 \\
(54 \%)\end{array}$ \\
\hline Number of instances for metalinguistic purposes & $\begin{array}{l}11 \\
(42 \%)\end{array}$ & $\begin{array}{l}17 \\
(40 \%)\end{array}$ & $\begin{array}{l}20 \\
(37 \%)\end{array}$ \\
\hline Number of instances for sociocultural purposes & $\begin{array}{l}1 \\
(4 \%)\end{array}$ & $\begin{array}{l}4 \\
(9 \%)\end{array}$ & $\begin{array}{l}5 \\
(9 \%)\end{array}$ \\
\hline Number of instances for metacognitive purposes & $\begin{array}{l}1 \\
(4 \%)\end{array}$ & 0 & 0 \\
\hline A total number of the four purposes & $\begin{array}{l}26 \\
(100 \%)\end{array}$ & $\begin{array}{l}42 \\
(100 \%)\end{array}$ & $\begin{array}{l}54 \\
(100 \%)\end{array}$ \\
\hline
\end{tabular}

The Purposes for Written Translanguaging and Why They Translanguaged

Drawing from integrated linguistic resources for sociolinguistic purposes. The most frequent function that characterized all three third-graders' translanguaging was their sociolinguistic competence. The students appropriately employed their two languages through translanguaging to facilitate their thinking and writing. The following examples demonstrate the unique bilingual abilities of the third-graders to draw from two languages or from the dual-language lexicon to express themselves as bilingual writers. Sometimes, the students translanguaged when they could not remember or did not know the equivalent words or the correct spellings in Korean. Their translanguaging in the above situation resulted in their continual writing without interruption.

Figure 1 shows Julie's in-class writing sample when she wrote about the differences between the Korean and English languages. As shown, Julie composed her texts using Korean only. Yet, close analysis of her text labels in the spaces for drawing shows the presence of translanguaging. Julie wrote the word "English" on the left side and the word "Korean" on the right side. She then provided English alphabets (A, B, C, D ...) for the word "English" and Korean letters (가,나,다...) for the word "Korean" to differentiate different linguistic features between the two languages. Then, she presented the symbol $(>)$ to indicate that she liked the English alphabets more than the Korean letter characters. Julie's translanguaging illustrates how she identified different linguistic features from the two languages by using her sociolinguistic knowledge (The English translations of the writing samples are at the end of the Figures).

One of Suji's in-class writing in Figure 2 shows a similar pattern. In this particular writing, Suji also wrote about the differences between the Korean and English languages. As shown, Suji composed her texts using both Korean and English. Suji engaged in writing by using Korean first, and then she translanguaged into English to complete the second part of her writing. This pattern (switching the languages entirely during composition) was uniquely observed in Suji's writing only throughout the third-graders' writing samples.

Suji explained during the interview that she was composing in the language she was thinking about: (translated into English) "I wrote in English when I thought about the English language, and I wrote in Korean when I thought about the Korean language". Suji's writing in this excerpt, along with her explanation, illustrates that she is a bilingual writer who demonstrated her sociolinguistic competence by utilizing both linguistic features from both languages she utilized the translanguaging strategy. 


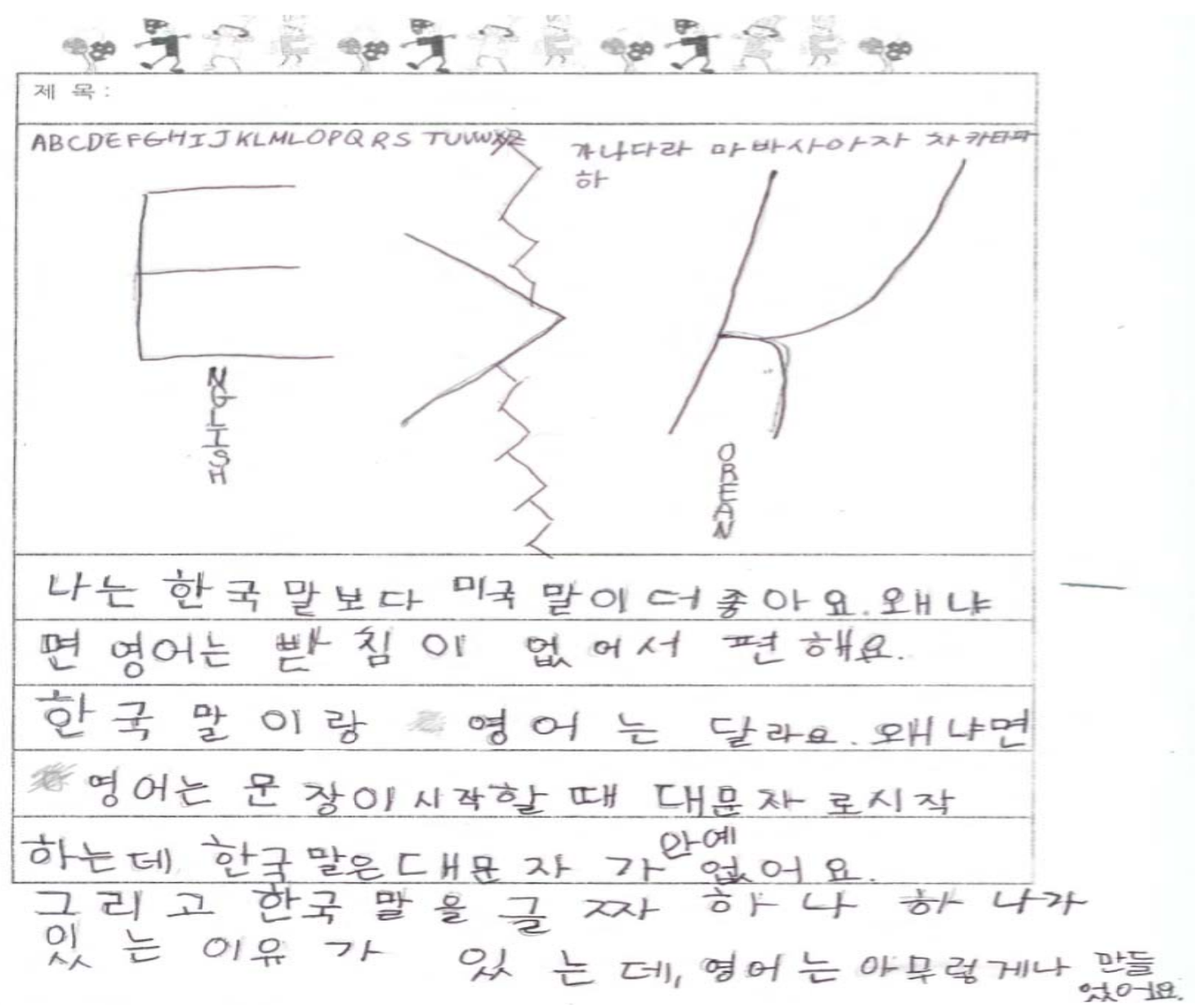

Figure 1. Using different linguistic features from both languages.

English translation of her writing: I prefer the English language to the Korean language. English is easy because it does not have batchim [Korean final consonants placed under the vowels]. Korean and English are different. English has capital letters, but Korean does not have them. And Korean has individual meaning in each letter, but English words can be made by combining letters.

Demonstrating metalinguistic awareness by manipulating written languages. The second most frequent function that characterized the third-graders' written translanguaging was their metalinguistic awareness. The students demonstrated their metalinguistic awareness through translanguaging when they self-regulated their language choices and showed that they understood when to use each language in different spaces. It is often found that the students wrote Korean in the body of their texts but used English in the spaces for drawings. The students' answers during the interviews helped to explain why they tended to use Korean in the texts but English to describe their drawings. For instance, Suji explained that writing at the Korean HL school should be in Korean, but providing text labels to describe her drawings was not authentic or official writing; thus, she can write them in English.

Figure 3 displays Suji's writing sample, which shows how she used Korean for one purpose and English for another purpose, demonstrating her metalinguistic awareness. Suji wrote her diary entirely in Korean, whereas, all the text labels around her drawings were written in English. In her written text, she translanguaged the English word and phrase that she had used to describe her drawings into Korean, which demonstrates that she differentiated her language use for main texts versus drawings. Close analysis displays that Suji wrote 
questions in English under her drawing asking, "Is it good? Yes or no. Circle one. Yes or no." Suji explained during the interview that she understood she had to write in Korean for her diary but thought that she could use English when it was not part of her diary:

(translated into English) I asked this question (the yes/no question) to myself to evaluate my drawing here. This is not part of my diary, so I used English. This (the top) is a place for drawing, and this (the bottom) is a place for writing.

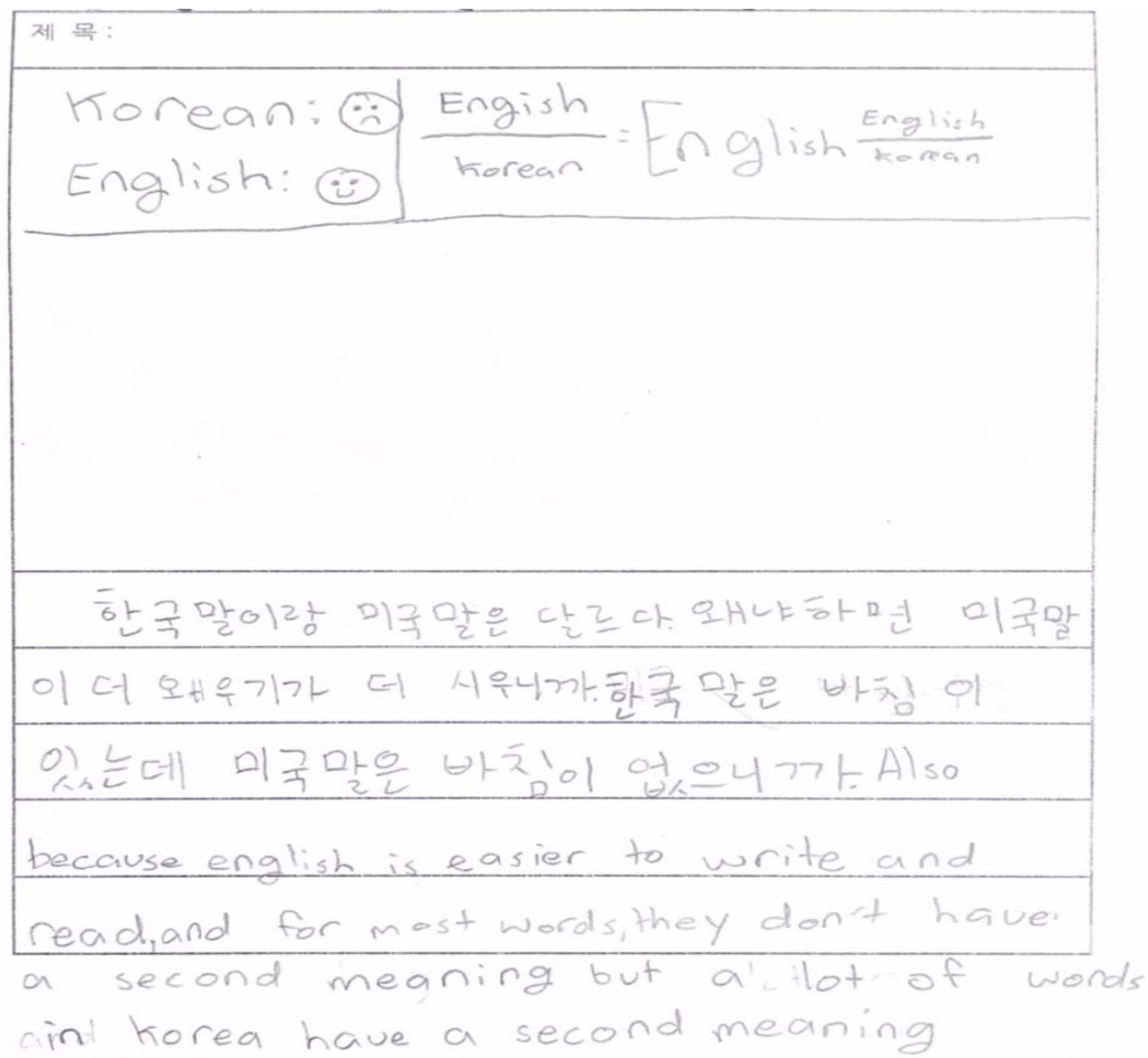

Figure 2. Integrating linguistic resources from both languages to compose.

English translation of her writing: Korean and English languages are different. That is because English is easier to memorize the words than Korean. Korean has batchims [Korean final consonants placed under the vowels], but English does not have them. Also, because [E]nglish is easier to write and read. [A]nd for most words, they don't have a second meaning but a lot of words in Korea[n] have a second meaning.

Translanguaging to communicate sociocultural knowledge. The students' use of translanguaging for the sociocultural function occurred when they used culturally familiar or relevant Korean words. Since the students did not produce any main texts in English (except for three English sentences by Suji; see Figure 2), their translanguaging for this function was observed when they wrote the bodies of texts in Korean and provided text labels for drawings in English. The students chose to write the words in Korean if they were specific to the Korean culture and customs, which demonstrated their cultural knowledge and understanding in Korean. 


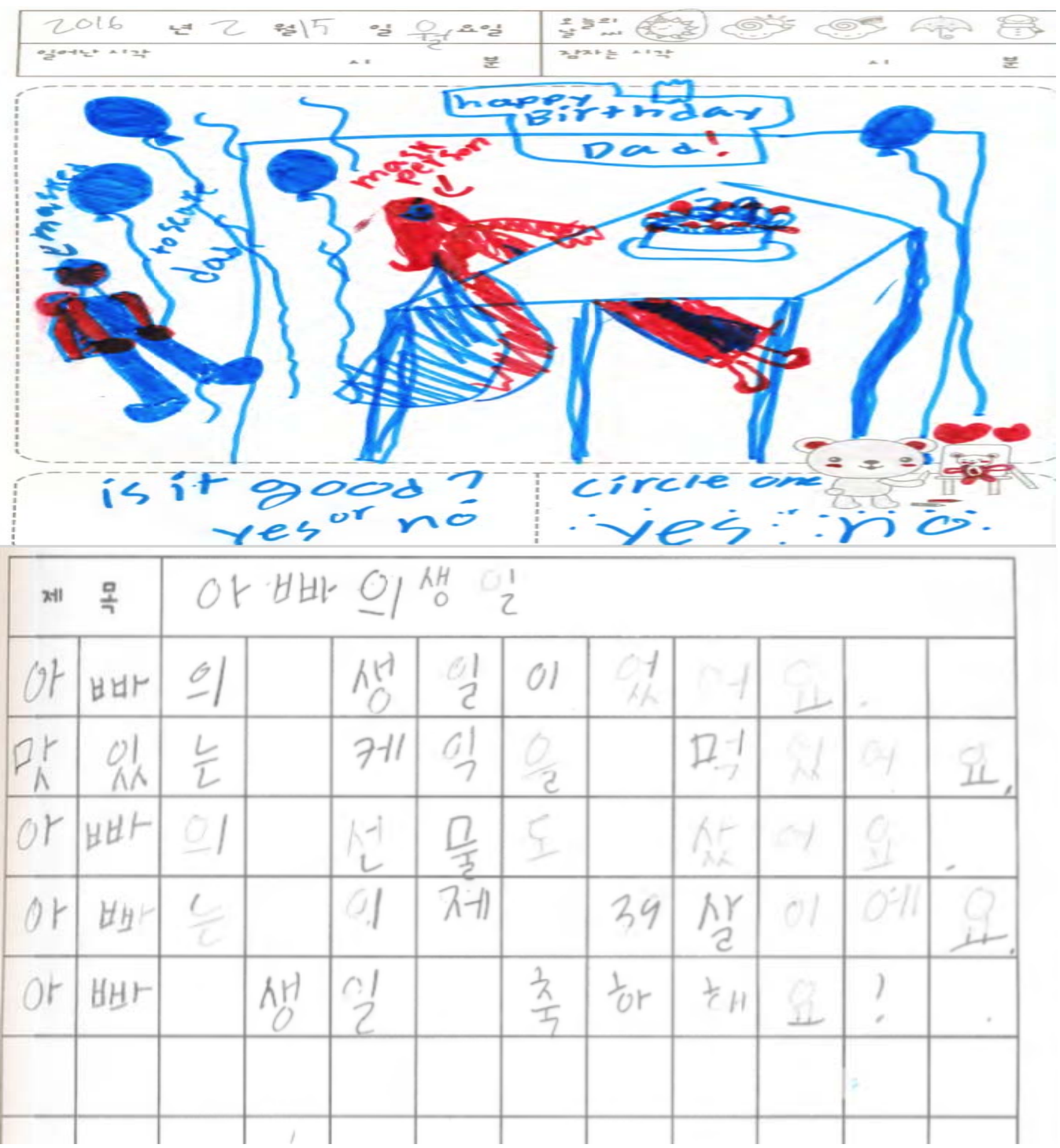

Figure 3. Using metalinguistic awareness to distinguish places for texts and drawings.

Title: My dad's birthday

Main texts: Today was my dad's birthday. We ate a delicious cake. I bought a birthday gift for him. My dad turned 39 years old. Happy birthday to my dad!

Text labels in drawings: masked, to scare dad, mask person, Happy birthday, Dad!

Figure 4 displays Suji's use of translanguaging to demonstrate her sociocultural knowledge when she provided text labels to her drawings both in Korean and English. Suji wrote her diary entry entirely in Korean but chose to use both languages when adding labels to describe her drawings. She provided several text labels in English ("School event", "fun", and "Yay") but added text labels in Korean for the words that are related to Korean culture ("Korean New Year's Day", "Korean food"). She further translanguaged for the English phrases by incorporating Korean words (italicized) that have cultural references ("making lucky bag" [symbols of luck in Korean], "wearing Hanbok" [traditional Korean clothes], and "making Jegi" [Korean traditional game]). The translanguaged phrases that included culturally specific Korean words indicated that Suji employed her sociocultural knowledge to describe each of the items in her drawings. 


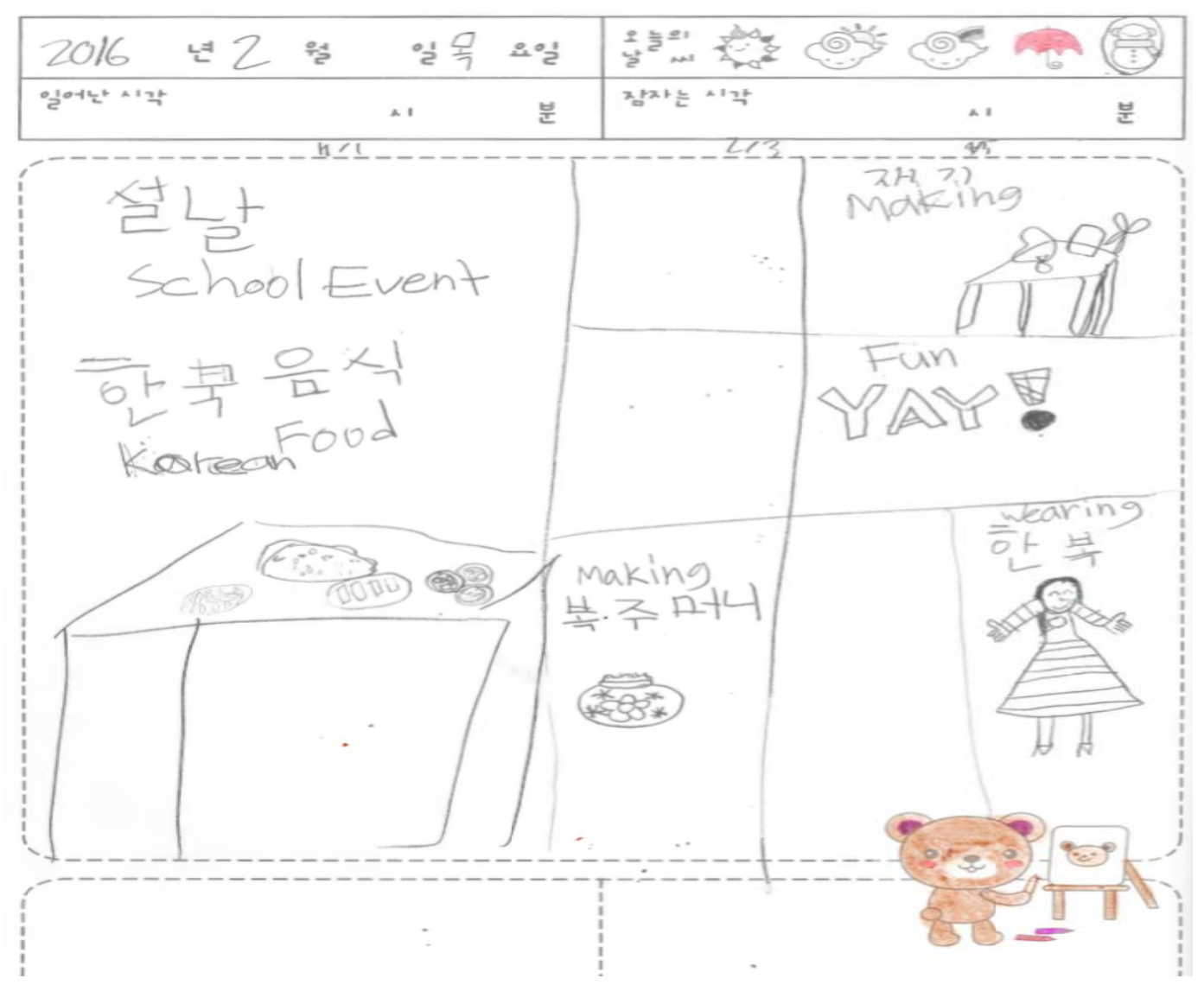

\begin{tabular}{|c|c|c|c|c|c|c|c|c|c|c|c|}
\hline \multicolumn{2}{|c|}{ 제 목 } & \multicolumn{10}{|c|}{ 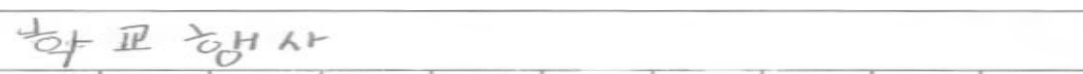 } \\
\hline 오 & $\frac{L}{2}$ & 은 & & $\frac{1}{2}$ & $\overrightarrow{\underline{P}}$ & $0-11$ & $x^{-1}$ & & 是 & $2 \Rightarrow$ & 설 \\
\hline 을 & & $a_{2}^{+}$ & or & & 만 & $\frac{O}{L}$ & & $2 H$ & Dו & $O_{M x}^{\prime}$ & $\frac{\mathrm{L}}{c}$ \\
\hline $7-1$ & $\frac{c}{c}$ & 01 & & OK & 에 & OH & 旦 & , & 足 & c & \\
\hline Dt & c & $>1$ & & $\lambda H$ & 21 & & pr & $\subseteq$ & 기 & & 복 \\
\hline 주 & $D-1$ & 4 & & $D_{2}$ & $\frac{5}{2}$ & גי & & $\frac{1}{o r}$. & 号 & & $\sigma_{H}^{\prime}$. \\
\hline 는 & & 것 & E & & 尙 & 어 & $o r$ & 요 & & 篮 & \\
\hline$\overline{\mathrm{ZH}}$ & a) & 众 & $O_{x i}$ & Or & 9 & 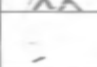 & of & Dr & $\neg r$ & & qr \\
\hline N-1 & & 도 & Qr & $\stackrel{\pi}{-}$ & OH & or & ii & 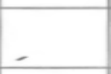 & 우 & 21 & ir \\
\hline$\square_{L}$ & $\frac{E}{L}$ & . & $D_{L}$ & ç & $\underline{I}$ & & $D-1$ & 武 & $0-1$ & 兵 & , \\
\hline & & & & & & & & & & & \\
\hline
\end{tabular}

Figure 4. Demonstrating sociocultural knowledge by adding culturally relevant Korean words.

Title: School Event

Today we celebrated the Korean New Year's Day at my school. There were many interesting things-making dumplings, making Jegi [the tool for Korean traditional game], making lucky bag [symbols of luck in Korean], and wearing Hanbok [traditional Korean clothes]. It was very fun. My mom came to help us. We ate the dumplings that we made together.

English text labels in drawing: School event, Korean Food, Fun, Yay!

Korean text labels in drawing: 설날 [Korean New Year's Day], 한국음식 [Korean food], making 재기, making 복주머니, wearing 한복. 
Figure 5 exhibits a similar translanguaging pattern in Julie's diary writing. As shown, Julie added text labels to her drawings in English for the places in the U.S. (i.e., Chicago trip, museum, shopping center, hotel, and inside the restaurant), but she chose to write her family members ("mom", "dad", and "younger sister") in Korean. Julie's explanation of her language use showed that she selected Korean to refer to her family because Korean represented her sociocultural upbringing: (translated into English) "I prefer to call mom and dad in Korean. Because... if I call mom and dad (in English), I feel like I am not that close to them”.

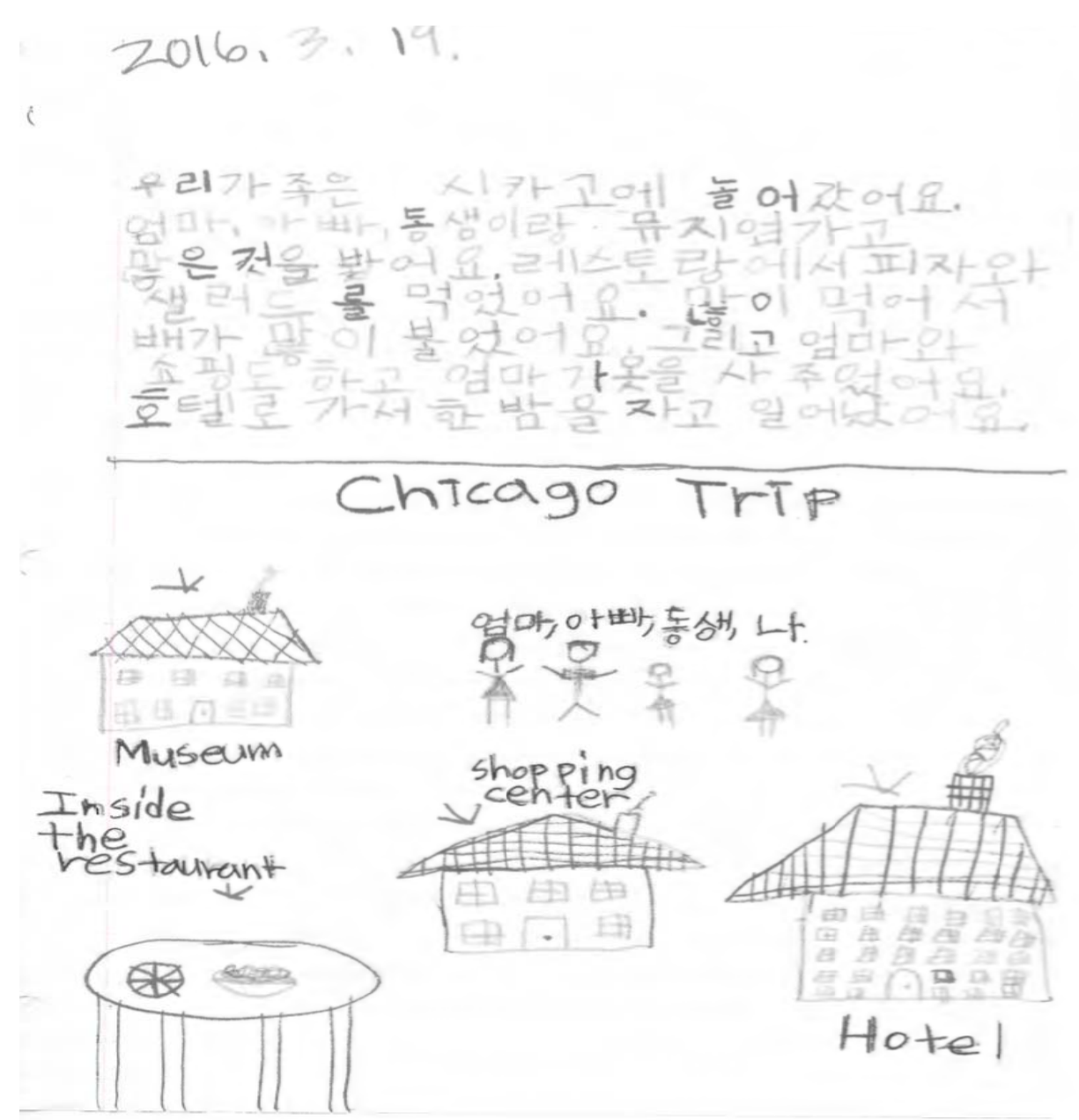

Figure 5. Selecting Korean words when referring to family members.

My family went to Chicago. I went to a museum with my mom, dad, and younger sister, and we saw many things there. We ate pizza and salad at the restaurant. I was full because I ate a lot. I went shopping with my mom. My mom bought pretty clothes for me. We went to the hotel and stayed a night there.

English text labels in drawing: Chicago trip, Museum, Shopping center, Hotel, Inside the restaurant Korean text labels in drawing: 엄마 [mom], 아빠 [dad], 동생 [younger sister], 나 [me]

Identifying metacognitive insight through inner speech. The students' metacognitive skills were witnessed when they engaged in self-thinking processes for their writing through inner speech. However, since I was not the teacher for the third-grade students, it was difficult to capture data on the students' self-talk from the audio-recordings of their class interactions. However, there was one example of Toni's use of translanguaging in his thinking and self-directed talk that revealed his metacognitive insight. 
In Figure 6, Toni introduced his cousin's names both in English and Korean at the beginning of the entry, but he only used his cousin's Korean name when he referred to him in the rest of his diary. Indeed, after introducing both names (in English and Korean), there was a trace of his using the English name, which Toni erased, later replacing it with the Korean name. During the interview, Toni explained:

(translated into English) I came up with the English name first because I call him by his English name, but I erased it and rewrote it with his Korean name because I knew that this was my Korean diary homework, so I talked to myself that I should write it in Korean.

When Toni switched his cousin's name from English to Korean, it appeared that he was using his metacognitive insight as he was monitoring and controlling his language use. Toni's statement during the interview suggested that he understood that he had to use Korean for his cousin's name by recognizing that he was writing his diary in Korean. This example demonstrates that Toni was able to manipulate his cognitive process and thinking through translanguaging, which implies that he was using his metacognitive skills.

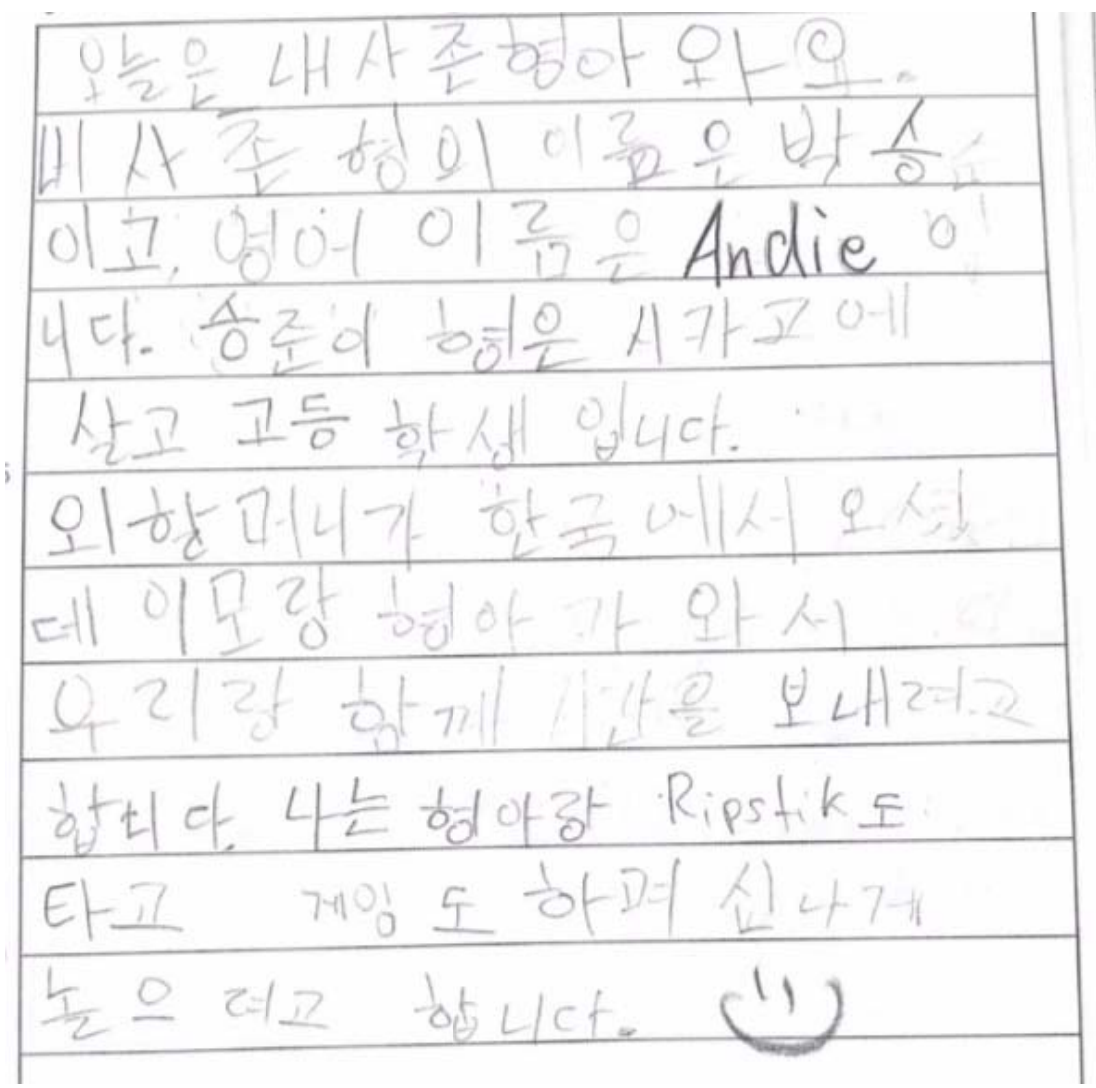

Figure 6. Translanguaging to show metacognitive in sigh through inner speech.

English translation of his writing: My cousin will visit my house today. My cousin's name is Seungjoon Park, and his English name is Andie. Seungjoon lives in Chicago, and he is a high school student. Since my grandmother came to see us from Korea, we will have a great time with my aunt and Seungjoon. I will ride a Ripstik and play games with Seungjoon, and we will have a fun time together.

\section{Conclusion, Discussion, and Implications}

For this paper, I drew from the four categories to design and implement a study that would significantly contribute to the field's knowledge of young bilingual students' written translanguaging. I utilized sociocultural 
and heteroglossia perspectives to provide insights into for what purposes and why young bilingual children, from non-related languages, who still were in the process of becoming bilingual, utilized translanguaging while writing in a single language (Korean) setting.

The analysis of the written translanguaging practices displayed by the three Korean-American third-graders in 97 writing samples showed that their written translanguaging was not random but systematic. All the three students' written translanguaging addressed three purposes (in order of frequency): to demonstrate their sociolinguistic competence, metalinguistic awareness, and sociocultural awareness. One of the three students (Toni) additionally demonstrated his metacognitive insight through translanguaging.

The sociolinguistic purpose characterized the majority of the students' translanguaging. The three students demonstrated their sociolinguistic competence by appropriately employing translanguaging while writing according to the topic, task, and/or setting (Halliday \& Hasan, 1989). Translanguaging for sociolinguistic purposes allowed them to proceed with their writing by integrating linguistic resources from both languages (Canagarajah, 2013; Velasco \& García, 2014). They also translanguaged for sociolinguistic purposes when they drew from their entire linguistic resources to create bilingual texts that elaborated their thinking.

The second most frequent purpose for their written translanguaging was metalinguistic awareness. The students demonstrated their metalinguistic awareness when they separated their language use into two spaces on the written page similar to the Korean-English bilingual kindergartner in the Velasco and García's (2014) study. One of the students explained that she could use English in the text label for her drawing because it was not real or official writing. That is, the students identified the different linguistic features between their two languages and manipulated their written languages through translanguaging according to different places during compositions. Similar to the first-grade Korean EFL learners in the Nam's (2017) study, none of the Korean-American first graders were bothered by the structural differences in the Korean and English writing systems.

The students' demonstration of translanguaging for sociocultural purposes was minimal. When they did produce this type of translanguaging, it involved reference to Korean people, food, holidays, and/or traditions and primarily occurred in their diary entries. Although their uses of translanguaging for this function were infrequently observed, their use of Korean words, which were specific to Korean culture and customs, demonstrated their cultural awareness and understanding in Korean. More translanguaging for sociocultural purposes might have occurred if the teacher had provided books that portray Korean culture and customs and asked the class to write about their memories or experiences growing up as Korean-Americans.

Only one student demonstrated his metacognitive insight as he was engaging in self-directed dialogue and asking himself a question about the word choice in his writing. A student in Gort's (2012) study made a metacognitive statement when she was rereading and reviewing an English draft that she previously had written in Spanish. When the student found errors in her writing, she verbally articulated through self-talk what and how she would revise her writing in English. Similar to the student in Gort's study, Toni reflected on what he wrote and evaluated the effectiveness of the substitutions by engaging in his metacognitive thinking. This finding implies that when bilingual writers engage in self-directed talk through translanguaging, they are more likely to evaluate and reflect on what they wrote activating their metacognitive insight.

Overall, the findings showed how the Korean-American third-graders' written translanguaging enriched their written communication. The analysis of the three bilingual students' writing confirmed on a larger scale Velasco and García's (2014) finding that young bilingual students translanguage to plan, draft, think, and 
complete their compositions. I further documented a number of written translangauging practices that the students employed, such as translanguaging to draw from the dual lexicon, to facilitate communication without interruption, to signal official and unofficial writing, to resolve writing problems, and to signal cultural relevance, among others. As several researchers proposed that translanguaging while writing should be viewed as a unique bilingual writing strategy (Canagarajah, 2013; Velasco \& García, 2014), I agree with this premise and recommend that the written translanguaging practices that we documented to be considered unique bilingual writing strategies and encouraged in bilingual students' writing.

The monoglossic contexts in which most bilingual students are taught and assessed need to be re-evaluated. The three students in this study demonstrated written translanguaging for HL school assignments even though their writing instruction at the school was predominantly in Korean. I do not know the extent to which the teacher's occasional use of English to clarify what she had said in Korean might have prompted their translanguaging while writing. However, I wonder to what extent the Korean-American students in this study could have further advanced their writing if they had been explicitly taught how to employ their entire linguistic resources through translanguaging in their writing (Cummins, 2005). Given the findings, I am also concerned about limiting bilingual students to writing in only one language when their writing performance is assessed (Hopewell \& Escamilla, 2014).

Most importantly, the analysis of the three Korean-American first graders' written translanguaging revealed additional information about the nature of bilingual students' translanguaging. The natural way that the three students translanguaged while writing indicated that they were drawing from their integrated linguistic resources, and not employing their languages separately to complete their writing. The findings substantiated the use of the heteroglossic perspective to explain bilingual students' utilization of two languages while writing. To understand more about how bilingual students employ their languages while writing, I recommend that additional researchers study the written translanguaging of larger numbers of bilingual students in different languages, at different ages, and in different sociocultural contexts.

\section{Limitations}

This study had several limitations. First, the study included a small number of participants; it focused on three students only. Second, the study occurred during a semester for 14 weeks; thus, I was not able to track the students' use of written translanguaging over the school year. Third, this study did not examine the third-graders' written translanguaging practices in their homes or at American schools taught in English. Lastly, because I was not the teacher for the third-grade students, it was difficult to capture data on the students' inner speech from the audio-recordings of their writing-related talk (when they talked to themselves) during their compositions. Accordingly, there was a limited number of third-graders' translanguaging findings that served as their metacognitive insight in their written language use. Although I asked Mrs. Joen to audio-record student talk during their writing, I might have not captured the classroom context in detail nor understood some of the data accurately. For instance, I was able to hear the students' voices but could not see their non-verbal language (e.g., body gestures, facial expressions), which might have led to more precise analysis.

\section{References}

August, D., \& Shanahan, T. (2010). Response to a review and update on "Developing literacy in second-language learners: Report of the National Literacy Panel on Language Minority Children and Youth”. Journal of Literacy Research, 42(3), 341-348. 
Bakhtin, M. M. (1981). The dialogic imagination: Four essays. (M. Holquist, Ed., C. Emerson \& M. Holquist, Trans.). Austin: University of Texas Press.

Bauer, E. B., Presiado, V., \& Colomer, S. (2017). Writing through partnership: Fostering translanguaging in children who are emergent bilinguals. Journal of Literacy Research, 49(1), 10-37.

Bialystok, E. (1991). Metalinguistic dimensions of bilingual language proficiency. In Bialystok, E. (Ed.), Language processing in bilingual children (pp. 113-140). London, England: Cambridge University Press.

Canagarajah, A. S. (Ed.). (2013). Literacy as translingual practice: Between communities and schools. New York, NY: Routledge.

Canale, M., \& Swain, M. (1980). Theoretical bases of communicative approaches to second language teaching and testing. Applied Linguistics, 1, 1-47.

Cummins, J. (2005). A proposal for action: Strategies for recognizing heritage language competence as a learning resource within the mainstream classroom. Modern Language Journal, 89, 585-592.

Creese, A., \& Blackledge, A. (2010). Translanguaging in the bilingual classroom: A pedagogy for teaching and learning. The Modern Language Journal, 94, 103-115.

Durán, L., \& Palmer, D. (2014). Pluralist discourses of bilingualism and translanguaging talk in classrooms. Journal of Early Childhood Literacy, 14, 367-388.

Edelsky, C. (1986). Writing in a bilingual program: Había una vez. Norwood, NJ: Ablex.

Francis, D. J., Lesaux, N. K., \& August, D. (2006). Language of instruction. In D. August and T. Shanahan (Eds.), Developing literacy in second-language learners: Report of the National Literacy Panel on Language Minority Children and Youth (pp. 365-414). Mahwah, NJ: Lawrence Erlbaum.

García, O. (2009). Bilingual education in the 21st century: A global perspective. West Sussex, UK: Wiley-Blackwell.

García, O., \& Leiva, L. (2014). Theorizing and enacting translanguaging for social justice. In A. Blackledge and A. Creese (Eds.), Heteroglossia as practice and pedagogy (Vol. 20, pp. 199-216). Heidelberg, Germany: Springer.

García, O., \& Wei, L. (2014). Translanguaging: Language, bilingualism and education. Basingstoke, UK: Palgrave Macmillan.

García-Mateus, S., \& Palmer, D. (2017). Translanguaging pedagogies for positive identities in two-way dual language bilingual education. Journal of Language, Identity, \& Education, 6(4), 245-255.

Gee, J. P. (2012). How to do discourse analysis: A toolkit. New York, NY: Routledge.

Genesee, F., Geva, E., Dressler, C., \& Kamil, M. L. (2006). Synthesis: Cross-linguistic relationships. In D. August and T. Shanahan (Eds.), Developing literacy in second-language learning: Report of the National Literacy Panel on language minority children and youth (pp. 153-174). Mahwah, NJ: Lawrence Erlbaum.

Golberg, H., Paradis, J., \& Crago, M. (2008). Lexical acquisition over time in minority L1 children learning English as a L2. Applied Psycholinguistics, 29, 1-25.

Goldenberg, C. (2011). Reading instruction for English language learners. In M. Kamil, P. D. Pearson, E. B. Moje, and P. Afflerbach (Eds.), The handbook of reading research (Vol. 4, pp. 684-710). New York, NY: Routledge.

Gort, M. (2012). Code-switching patterns in the writing-related talk of young emergent bilinguals. Journal of Literacy Research, 44(1), 45-75.

Halliday, M. A. K., \& Hasan, R. (1989). Language, context, and text: Aspects of language in social-semiotic perspective. London: Oxford University Press.

Hopewell, S., \& Escamilla, K. (2014). Struggling reader or emerging biliterate student? Reevaluating the criteria for labeling emerging bilingual students as low achieving. Journal of Literacy Research, 46(1), 68-89. doi:10.1177/1086296X13504869

Lee, C., \& García, E. G. (2020). Unpacking the oral translanguaging practices of Korean-American first graders. Bilingual Research Journal, 43(1), 32-49.

McCarthey, S., Idelia, N., \& Lee, C. (2019). Translanguaging across contexts. In M. Dressman and R. Sadler (Eds.), The handbook of informal language learning (pp. 349-367). Oxford: John Wiley \& Sons Ltd.

Meichenbaum, D. (1985). Teaching thinking: A cognitive-behavioral perspective. In S. F., Chipman, J. W. Segal, and R. Glaser (Eds.), Thinking and learning skills, Vol. 2: Research and open questions. Hillsdale, NJ: Lawrence Erlbaum Associates.

Mertens, D. M. (2015). Research and evaluation in education and psychology: Integrating diversity with quantitative, qualitative, and mixed methods (4th ed.). Thousand Oaks, CA: Sage.

Nam, K. M. (2017). How young children make sense of two different writing systems: Korean written in the Hangul alphabet, and English written in the Roman alphabet. Journal of Early Childhood Literacy, 18(4), 490-517.

Ro, Y. E., \& Cheatham, G. A. (2009). Biliteracy and bilingual development in a second-generation Korean child: A case study, Journal of Research in Childhood Education, 23, 290-308. 
Slavin, R. E., \& Cheung, A. (2005). A synthesis of research on language of reading instruction for English language learners. Review of Educational Research, 75(2), 247-284.

Soltero-Gonzalez, L., \& Butvilofsky, S. (2016). The early Spanish and English writing development of simultaneous bilingual preschoolers. Journal of Early Childhood Literacy, 16(4), 473-497.

Street, B. (2001). Introduction. In B. Street (Ed.), Literacy and development: Ethnographic perspectives (pp. 1-17). London: Routledge.

Velasco, P., \& García, O. (2014). Translanguaging and the writing of bilingual learners. Bilingual Research Journal, 37(1), 6-23.

Wei, L. (2018). Translanguaging as a practical theory of language. Applied Linguistics, 39(1), 9-30. 